\title{
Stretch-Activated Channels in Human Retinal Muller Cells
}

\author{
DONALD G. PURO \\ Departments of Ophthalmology and Physiology, University of Michigan School of Medicine, Ann Arbor, \\ Michigan 48105
}

KEY WORDS Glia, Ion channels, Cations, Cell swelling

\begin{abstract}
The cell-attached and excised patch configurations of the patch clamp technique were used to study stretch-activated ion channels in Muller glial cells that were obtained from postmortem adult human retinas and were maintained in culture. A stretch-activated channel permeable to monovalent and divalent cations was found. Ion channels of this type have not been demonstrated previously in glial cells, though indirect evidence has suggested that such stretch-activated channels may help mediate a compensatory response of glia to swelling. Consistent with a possible role for volume regulation is the finding that the activation of calcium-permeable stretch-sensitive channels is associated with an increase in the activity of calcium-activated potassium channels. Activation of potassium channels to produce an efflux of potassium with a subsequent loss of anions and cell water could be an effective mechanism to decrease glial cell volume.
\end{abstract}

\section{INTRODUCTION}

Under a variety of pathological conditions, glial cells of the CNS swell (Kimelberg and Ransom, 1986). The swelling of glia may contribute to irreversible damage to the nervous system associated with ischemia, trauma, and other adverse conditions. Experimental studies suggest that glial cells have regulatory mechanisms to limit swelling (Kimelberg and Goderie, 1988) and, thus, to reduce the risk of damage from an excessive volume increase. Assays of ion fluxes and membrane potentials in cultured astrocytic glia have provided indirect evidence suggesting that one possible mechanism for a compensatory volume decrease after swelling may involve ion channels that are activated by stretching of the cell membrane and that are nonspecifically permeable to cations (Kimelberg and O'Connor, 1988). In addition, patch clamp studies of epithelial cells (Christensen, 1987) indicate that an influx of calcium through stretchactivated channels opened in response to cell swelling may activate calcium-sensitive potassium channels resulting in an outflux of potassium followed by anions and cell water. However, the existence of such stretchactivated channels in glial cells has not been directly demonstrated. In this report the patch clamp technique was used to establish the presence in human retinal
Muller cells of stretch-activated ion channels that are permeable to monovalent and divalent cations.

\section{MATERIALS AND METHODS}

Cultures of retinal glial cells were prepared as described previously (Puro et al., 1990; Puro and Mano, 1991). In brief, postmortem eyes from donors aged 62 to 81 years were supplied within $24 \mathrm{~h}$ of death by the Florida Lions and Michigan Eye Banks. Retinas were removed, exposed to a calcium- and magnesium-free phosphate buffer supplemented with $0.1 \%$ trypsin $(\times 3$ crystallized, Worthington), $0.2 \%$ hyaluronidase (Sigma), and $4 \%$ chicken serum (GIBCO) for $45 \mathrm{~min}$ at $37^{\circ} \mathrm{C}$ and then dissociated mechanically in $80 \%$ medium A (1:1 ratio of Dulbecco's modified Eagle's medium and Ham's F-12 medium) and 20\% fetal bovine serum. Dissociated cells were added to plastic Petri dishes, kept in a humidified environment of $97 \%$ air and $3 \% \mathrm{CO}_{2}$ at $37^{\circ} \mathrm{C}$, fed twice per week with $80 \%$ medium $\mathrm{A}$ and $20 \%$ fetal bovine serum, and split when they reached conflu-

\footnotetext{
Received February 1, 1991; accepted April 19, 1991.

Address reprint requests to Dr. Donald G. Puro, University of Michigan, W.K. Kellogg Eye Center, 1000 Wall Street, Ann Arbor, MI 48105.
} 
ency. Cells that had been in culture for two to four passages were used. As reported elsewhere, virtually all of the cells stained positively for glial fibrillary acidic protein (Mano and Puro, 1990; Puro et al., 1990). Ultrastructural studies of these cultured cells have demonstrated the presence of $10 \mathrm{~nm}$ cytoplasmic filaments (Mano and Puro, 1990; Puro et al., 1990), which are characteristic of glial cells. In addition, as published previously (Puro et al., 1990), nearly all the cells in these cultures stained positively by immunocytochemistry with a monoclonal antibody for Muller cells (Chan et al., 1984).

Ion currents were recorded with the patch clamp technique using the cell-attached and excised patch configurations (Hamill et al., 1981). One day prior to recording, cultures were washed twice and kept in medium B (medium A supplemented with $50 \mu \mathrm{g} / \mathrm{ml}$ transferrin and $30 \mathrm{nM}$ sodium selenite). Approximately 1 to $2 \mathrm{~h}$ prior to recording, medium $B$ was replaced with bathing solution. Unless stated otherwise, the bathing solution consisted of $140 \mathrm{mM} \mathrm{K}$-aspartate, $4 \mathrm{mM} \mathrm{CaCl}_{2}$, $1 \mathrm{mM} \mathrm{MgCl}_{2}, 10 \mathrm{mM}$ glucose, and $10 \mathrm{mM} \mathrm{K}$-HEPES ( $\mathrm{pH}$ 7.3). Although it is not known whether aspartate is taken up into the human retinal glial cells or activates glutamate receptors, this bathing solution appeared to zero the resting membrane potential because unitary currents generally remained unchanged after patch excision though voltage shifts occasionally were detected after excision, which indicated a maximum voltage error of $\sim 10 \mathrm{mV}$. For excised patches, the bathing solution was changed to one containing $10^{-8} \mathrm{M} \mathrm{Ca}^{2+}$ unless otherwise noted. Pipets were filled with $100 \mathrm{mM}$ $\mathrm{BaCl}_{2}$ and $10 \mathrm{mM} \mathrm{Ba-HEPES}$ (pH 7.3) or other solutions as noted.

Currents were recorded with a Dagan 8900 patch clamp amplifier having a $10 \mathrm{Gohm}$ headstage. Firepolished pipets of borosilicate glass $(1.5 \mathrm{~mm}$ diameter, fiber-filled, WPI) coated with Sylgard no. 184 (Dow Corning) had resistances of 6-9 Mohms. Pipet potentials were adjusted to zero current flow before establishment of seals. Junction potentials were not subtracted. Membrane-pipet seals were $>10 \mathrm{Gohm}$. Suction (120 $\mathrm{mm} \mathrm{Hg}$ ) was applied to the patch pipet through the sidearm of the pipet holder and was monitored by a pneumatic transducer (BioTek). Current signals were filtered at $1 \mathrm{kHz}$. Ion currents could be digitalized (Neurocorder, Neuro Data Instr.) and stored on videotape for later analysis. Measurements of the percent of time that an ion channel was opened were made as described elsewhere (Puro, 1991). In brief, an increase in current greater than $50 \%$ of the unitary channel current was interpreted as a channel opening. Once open, a decrease in the current to $50 \%$ of the single channel level was defined as a channel closing. Computer software (pClamp, version 5.5, Axon Instr.) aided in the assessment of percent open time, which was determined for $2 \mathrm{~s}$ periods. A solution could be miniperfused in the area of an excised patch by applying $0.5 \mathrm{psi}$ of pressure from a pressure ejection system (Medical Systems) to the back end of a pipet with a tip size of approximately 5-10 $\mu \mathrm{m}$. Experiments were carried out at room temperature, approximately $22^{\circ} \mathrm{C}$.

\section{RESULTS}

In 13 of 15 (87\%) cell-attached patches sampled from human retinal Muller cells, ion channel activity could be elicited by applying suction to the patch pipet. In most cases, ion channels sensitive to stretch were relatively inactive prior to the application of suction (Fig. 1). Typically, multiple channels of similar unitary conductances opened during suction, as illustrated in Figure 1. With isotonic barium in the patch pipet, the mean channel conductance between $-100 \mathrm{mV}$ to $-30 \mathrm{mV}$ for stretch-activated channels was $32 \mathrm{pS}(\mathrm{SD}=4, \mathrm{n}=6)$.

The ionic selectivity of the stretch-activated channels was investigated using excised inside-out patches. Permeability to chloride is minimal since replacement of aspartate with chloride in the bathing solution did not significantly change the reversal potential or conductance. Figure 2 shows that these stretch-activated channels in retinal glial cells are permeable to both monovalent $\left(\mathrm{Na}^{+}, \mathrm{K}^{+}\right)$and divalent $\left(\mathrm{Ca}^{2+}, \mathrm{Ba}^{2+}\right)$ cations. The current-voltage relationships in Figure 2 reveal some inward rectification. Precise determination of the reversal potentials is difficult due to nonlinearity of the current-voltage plots and the small amplitudes of current openings between $\pm 30 \mathrm{mV}$.

The activity of the stretch-activated cation channels did not appear to be dependent on intracellular calcium levels because sensitivity to stretch persisted when the cytoplasmic surface of an excised patch was bathed in a solution containing $1 \mathrm{mM}$ EGTA and no added calcium. Changing the membrane potential from -100 to +100 $\mathrm{mV}$ failed to open this type of channel in the absence of the application of suction. Also, a voltage dependence of channel gating was not evident during stretch activation, though a modest effect of voltage would have been difficult to detect since the activity of these channels was unstable despite an application of a constant amount of suction (Fig. 1). Similar nonstationary behavior has been found in studies of other stretch-activated channels (Sachs, 1988).

Experiments were performed to help examine the possibility that an influx of calcium via stretch-activated channels may activate calcium-sensitive potassium channels resulting in a potassium efflux, which subsequently could lead to an outflow of cell water. The activity of large conductance calcium-activated potassium channels (so-called BK channels), which have been described previously in cultured retinal glia (Puro et al., 1989), was monitored in cell-attached patches with or without calcium at the extracellular side and in excised inside-out patches. In three of four cell-attached patches with calcium ( $37 \mathrm{mM}$ ) in the pipet solution, an increase in activity of BK channels associated with the application of suction to the pipet was detected (e.g., Fig. 3A,B). In contrast, with low calcium ( $1 \mathrm{mM}$ EGTA and no calcium added) in the pipet, suction on a cell-attached 


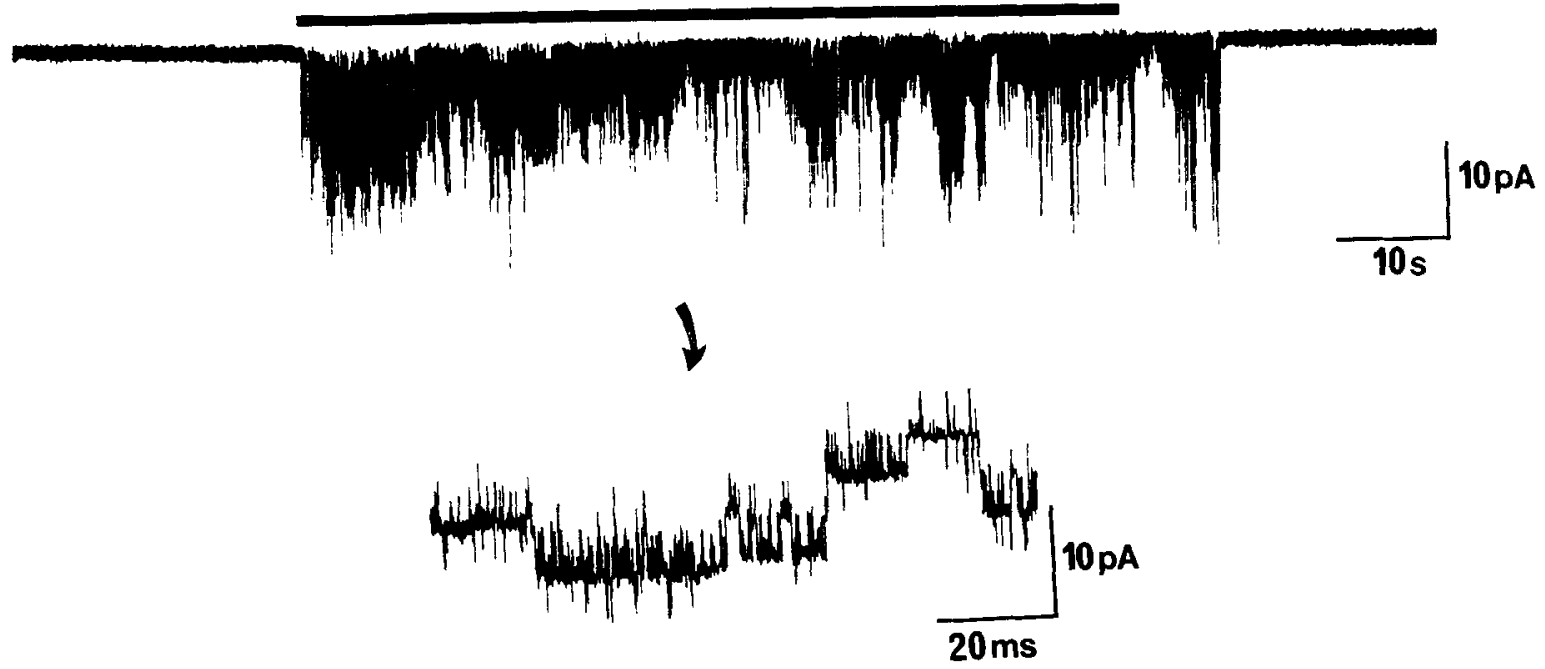

Fig. 1. Stretch-activated ion channels in a human retinal glial cell in culture. The top panel shows current records from a cell-attached patch. The bar above the record marks the period of application of suction $(-120 \mathrm{~mm} \mathrm{Hg})$ to the recording pipet. The arrow points to a current record displayed at a faster time scale. A downward deflection of the current record indicates an inward current, i.e., positive current passing from the pipet into the cell. Solutions in the bath and pipet were as stated in the Materials and Methods section. A potential of $+90 \mathrm{mV}$ was applied to the pipet.

patch did not elicit a change in BK activity ( 0 in 4). Also, BK channels in excised patches were not affected by stretch. These experiments indicate that a stretch-induced increase in BK activity requires a cell-attached patch with calcium at the extracellular surface. Since previous studies (Pallotta et al., 1981) demonstrated that BK channels are not sensitive to extracellular calcium, a stretch-sensitive pathway for calcium to enter the cell is likely to account for the increased activity of BK channels in cell-attached patches observed when suction was applied to the recording pipet.

One cell-attached patch showing a stretch-associated increase in BK activity is illustrated in Figure 3. When suction was applied to the cell-attached patch, the percent of time that the BK channel was opened increased approximately threefold (Fig. 3A,B). When studied under hyperpolarizing conditions to silence the BK channels and to enhance detection of channels with depolarizing reversal potentials, stretch-activated ion channels with inward currents, with extrapolated reversal potentials near $0 \mathrm{mV}$, and with unitary conductances of approximately $35 \mathrm{pS}$ were also found to be present in the cell-attached patch (Fig. $3 \mathrm{C}$ ). The characteristics of the channels in Figure 3C are consistent with stretch-activated channels of the type studied in Figures 1 and 2 . Thus, these channels provided stretchsensitive pathways for calcium to enter the glial cell. Figure 3D confirms that the BK channel studied in Figure 3 was sensitive to calcium on its cytoplasmic side when examined in an inside-out excised patch. The findings in Figure 3 are consistent with the hypothesis that calcium entering a glial cell via stretch-activated channels can active calcium-sensitive potassium channels.
These experiments support the possibility that the stretch-activated channels described here may indirectly regulate potassium fluxes and, thereby, play a role in cell volume regulation. However, I was unable to detect an increase in the activity of stretch-activated channels in cell-attached patches during glial swelling induced by exposure to a hypotonic ( $150 \mathrm{mOsm})$ bathing

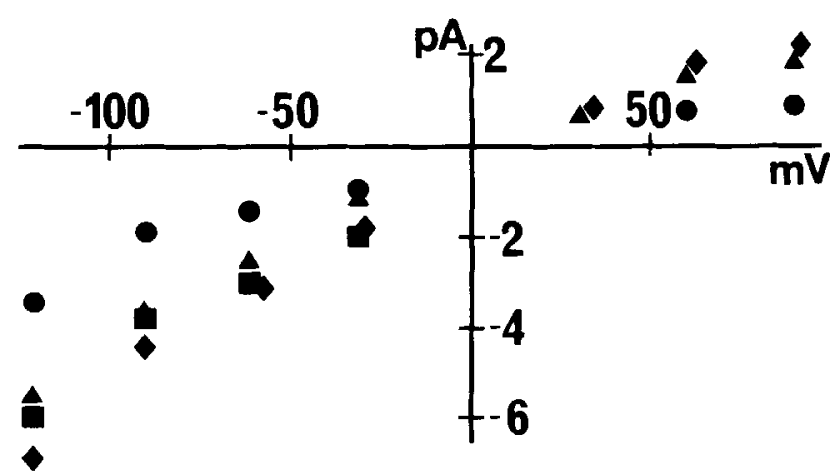

Fig. 2. Current-voltage relationships of stretch-activated channels in excised, inside-out patches recorded with pipets containing various ionic solutions. Points show unitary current amplitudes measured at $30 \mathrm{mV}$ intervals between $-120 \mathrm{mV}$ to $+120 \mathrm{mV}$ for pipet solutions containing $100 \mathrm{mM} \mathrm{BaCl}_{2}$ (squares), $100 \mathrm{mM} \mathrm{CaCl}_{2}$ (circles), $137 \mathrm{mM}$ $\mathrm{NaCl}$ (triangles), and $137 \mathrm{mM}$ KCl (diamonds). Each set of points represents results from a single patch; each point shows the mean of three determinations. The unitary conductance between $-90 \mathrm{mV}$ and $-30 \mathrm{mV}$ was $17 \mathrm{pS}, 32 \mathrm{pS}, 40 \mathrm{pS}$, and $50 \mathrm{pS}$ with isotonic $\mathrm{Ca}^{2+}, \mathrm{Ba}^{2+}$, $\mathrm{Na}^{+}$, and $\mathrm{K}^{+}$in the pipet, respectively. Five of the diamond symbols are displaced slightly to the right to aid in viewing. All solutions were buffered to 7.3 with HEPES. The bathing solution contained $140 \mathrm{mM}$ $\mathrm{K}^{+}$as noted in the Materials and Methods section. 


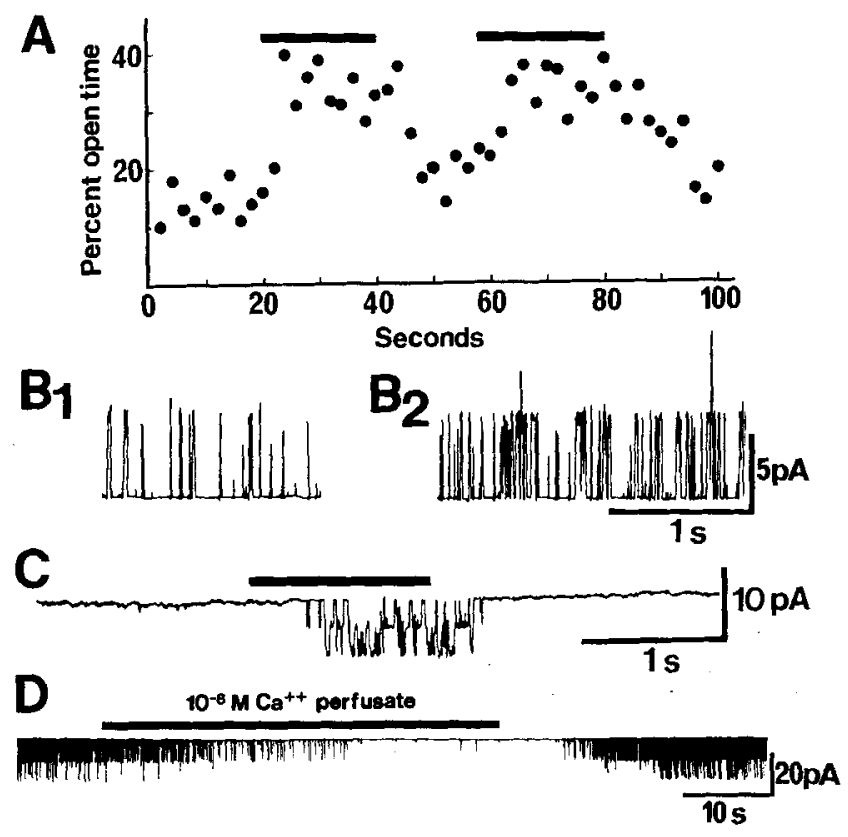

Fig. 3. Stretch-associated increase in the activity of a calciumactivated potassium channel. A: Percent of time that $\mathrm{B}$ BK channel in a cell-attached patch was opened. Bars show the periods of application of suction $(-90 \mathrm{~mm} \mathrm{Hg})$ to the patch pipet. Solutions in the bath contained $137 \mathrm{mM} \mathrm{NaCl}, 5.4 \mathrm{mM} \mathrm{KCl}, 2 \mathrm{mM} \mathrm{CaCl}, 1 \mathrm{mM} \mathrm{MgCl}_{2}, 10 \mathrm{mM}$ glucose, and $10 \mathrm{mM}$ Na-HEPES. The pipet solution was similar except that $37 \mathrm{mM} \mathrm{CaCl}{ }_{2}$ and $100 \mathrm{mM} \mathrm{NaCl}$ were present. A potential of -50 $\mathrm{mV}$ was applied to the pipet. B: Current records of the patch studied in A. Records B1 and B2 are from prior to and during the first application of suction, respectively. Upward deflections indicate channel openings. C: Current recording revealing stretch-sensitive channels in the same cell-attached patch as studied in $\mathrm{A}$ and $\mathrm{B}$. A hyperpolarizing potential of $+30 \mathrm{mV}$ was applied to the pipet to silence BK channels and to enhance the amplitude of stretch-activated channels having reversal potentials near $0 \mathrm{mV}$. The bar above the record shows the period of application of suction $(-90 \mathrm{~mm} \mathrm{Hg}$ ). Two channels with inward current were activated during the period of suction. The apparent delay in the onset of the stretch-activated current may not be significant due to the slow, uncertain time course for the onset of maximal suction. D; Calcium sensitivity of the $\mathrm{BK}$ channel. The same patch as in $\mathrm{A}-\mathrm{C}$ was studied after excision to the inside-out configuration. Prior to excision, the bathing solution was changed to one containing $10 \mu \mathrm{M} \mathrm{CaCl}{ }_{2}$. The bar above the current record shows the period of time during which the patch was in a local perfusate containing $10 \mathrm{nM}$ calcium $(0.32 \mathrm{mM}$ $\mathrm{CaCl}_{2}+1 \mathrm{mM}$ EGTA). Downward deflections of the current record indicate channel openings. The potential applied to the pipet was $+55 \mathrm{mV}$.

solution. Perhaps, under the conditions used here, the patch of membrane within the recording pipet was not stretched significantly as the cell volume increased.

\section{DISCUSSION}

The results show that human retinal Muller cells in culture have stretch-activated ion channels that are permeable to monovalent and divalent cations. These ion channels are similar to the stretch-activated nonspecific cation channels found in epithelial cells of the salamander choroid plexus (Christensen, 1987) and in porcine vascular endothelium (Lansman et al., 1987). Calcium-permeable stretch-activated channels are also present in murine skeletal myotubes (Franco and Lans- man, $1990 \mathrm{a}, \mathrm{b})$, though these channels have a smaller conductance than the ones found in this study. The only stretch-activated channels previously identified in glial cells are selective for potassium (Ding et al., 1989).

The role of stretch-activated channels in cells other than mechanoreceptors remains uncertain. However, a function in the regulation of cell volume is suspected (Christensen, 1987; Kulberg, 1988; Sachs, 1988). Studies of epithelial cells suggest that swelling activates calcium-permeable stretch-sensitive channels, causing an influx of calcium that activates calcium-sensitive potassium channels to produce an efflux of potassium, and, subsequently, anions and cell water resulting in a decrease in cell volume (Christensen, 1987). Since retinal Muller cells also contain both stretch-activated nonspecific cation channels and calcium-activated potassium channels (Puro et al., 1989), a similar sequence may take place in these cells.

Experiments presented here suggest that an influx of calcium via stretch-activated cation channels is necessary for stretch to activate calcium-activated potassium channels in cultured Muller cells. By providing a stretch-sensitive pathway for calcium to enter a Muller cell, stretch-activated channels may help limit glial swelling by enhancing the efflux of potassium, anions, and cell water. Although this study supports the hypothesis that stretch-activated channels may help limit glial swelling, it remains to be demonstrated that increasing the volume of a Muller cell actually alters its surface membrane and/or cytoskeleton sufficiently to activate stretch-activated channels. In addition, it is not known whether calcium-permeable stretch-activated channels play a role in the physiology and pathophysiology of glial cells from other parts of the CNS though it is known that cultured glia from the brain express calcium-activated potassium channels (Barres et al., 1990; Quandt and MacVicar, 1986).

Although enhancing potassium efflux via calciumactivated potassium channels would tend to protect glial cells from pathological volume increases, this would appear to be counter to the putative role of glia in removing excessive extracellular potassium released by depolarized neurons (Newman et al., 1984). However, if the calcium-activated potassium conductance of glial cells were located distant from neurons and near blood vessels or other non-neural sites, then an efflux of potassium indirectly induced by membrane stretch would tend to translocate potassium away from the neurons.

Despite compensatory mechanisms to limit glial swelling, swollen glia are a common finding in the severely damaged CNS (Kimelberg and Ransom, 1986). Undoubtedly many factors contribute to a failure to prevent a pathological swelling of glial cells. Stretchactivated calcium-permeable channels may be one contributing factor. Although serving to reduce volume, these channels may also play a role in damaging glia if a prolonged calcium influx via these channels results in a toxic overload of intracellular calcium leading to cell dysfunction, swelling, and death. 


\section{ACKNOWLEDGMENTS}

This work was supported by grants EY06931, EY02180, and EY07003 from the National Eye Institute, National Institutes of Health, Bethesda, MD.

\section{REFERENCES}

Barres, B.A., Chun, L.L.Y., and Corey, D.P. (1990) Ion channels in vertebrate glia. Annu. Rev. Neurosci., 13:441-474.

Chan, C.-C., Rosenszajn, L.A., Nussenblatt, R.B., MuellenbergCoulombre, C., Hsu, S.-M. Palestine, A.G., Lando, Z., and Ben Ezra, D. (1984) Monoclonal antibodies to Muller's cells of the retina. Invest. Ophthalmol. Vis Sci., 25:1008-1012.

Christensen, $O$. (1987) Mediation of cell volume regulation by $\mathrm{Ca}^{2+}$ influx through stretch-activated channels. Nature, 330:66-68.

Ding, J.P., Yang, X.C., Bowman, C.L., and Sachs, F. (1989) A stretchactivated ion channel in rat astrocytes in primary culture. Soc. Neurosci. Abstr., 15:1056.

Franco, Jr., A. and Lansman, J.B. (1990a) Calcium entry through stretch-inactivated ion channels in $\mathrm{mdx}$ myotubes. Nature, $344: 670-673$.

Franco, Jr., A. and Lansman, J.B. (1990b) Stretch-sensitive channels in developing muscle cells from a mouse cell line. J. Physiol., 427:361-380.

Hamill, D.P., Marty, A., Nehr, E., Sakmann, B., and Sigworth, F.J. (1981) Improved patch clamp techniques for high-resolution current recording from cells and cell-free membrane patches. Pflugers Arch. Ges. Physiol., 391:85-100,

Kimelberg, H.K. and Ransom, B.R. (1986) Physiological and pathological aspects of astrocytic swelling. In: Astrocytes, Vol. 3. S. Federoff and A. Vernadakis, eds. Academic Press, Orlando, pp. 129-166.
Kimelberg, H.K. and Goderie, S.K. (1988) Volume regulation after swelling in primary astrocyte cultures. In: Biochemical Pathology of Astrocytes. M.D. Norenberg, A. Schousboe, and L. Mertz, eds. Alan R. Liss, New York, pp. 299-311.

Kimelberg, H.K. and O'Connor, E. (1988) Swelling of astrocytes causes membrane potential depolarization. Glia, 1:219-224.

Kulberg, R. (1987) Stretch-activated ion channels in bacteria and animal cell membranes. Trends Neurosci., 10:38-39.

Lansman, J.B., Hallam, T.J., and Rink, T.J. (1987) Single stretchactivated ion channels in vascular endothelial cells as mechanotransducers? Nature, 325:811-813.

Mano, T. and Puro, D.G. (1990) Phagocytosis by human retinal glial cells in culture. Invest. Ophthalmol. Vis. Sci., 31:1047-1055.

Newman, E.A., Frambach, D.A., and Odette, L.L. (1984) Control of extracellular potassium levels by retinal glial cell $\mathrm{K}^{+}$siphoning. Science, 225:1174-1175.

Pallotta, B.S., Magleby, K.L., and Barrett, J.N. (1981) Single channel recordings of $\mathrm{Ca}^{2+}$-activated $\mathrm{K}^{+}$currents in rat muscle cell culture. Nature, 293:471-474.

Puro, D.G. (1991) A calcium-activated, calcium-permeable ion channel in human retinal glial cells: Modulation by basic fibroblast growth factor. Brain Res., 548:329-333.

Puro, D.G. and Mano, T. (1991) Modulation of calcium channels in human retinal glial cells by basic fibroblast growth factor: A possible role in retinal pathobiology. J. Neurosci., 11:1873-1880.

Puro, D.G., Roberge, F., and Chan, C.C. (1989) Retinal glial cell proliferation and ion channels: A possible link. Invest. Ophthalmol. Vis. Sci., 30:521-529.

Puro, D.G., Mano, T., Chan C.C., Fukuda, M., and Shimada, H. (1990) Thrombin stimulates the proliferation of human retinal glial cells. Graefes Arch. Clin. Exp. Ophthalmol., 228:169-173.

Quandt, F.N. and MacVicar, B.A. (1986) Calcium activated potassium channels ion cultured astrocytes. Neuroscience, 19:29-41.

Sachs, F. (1988) Mechanical transduction in biological systems. CRC Crit. Rev. Biomed. Eng., 16:141-169. 